\title{
PRINCIPLES OF MEDICINAL (LINIMENT) PREPARATIONS USING IN COMPLEX THERAPY OF WOUND INFECTION
}

\section{ПРИНЦИПИ ЗАСТОСУВАННЯ ЛІКАРСЬКИХ (МАЗЕВИХ) ЗАСОБІВ У КОМПЛЕКСНІЙ ТЕРАПІЇ РАНОВОЇ ІНФЕКЦЇ̈}

\author{
Khrystian Gennady ${ }^{1}$ \\ Torianyk Inna ${ }^{2}$ \\ Nevmergitscky Volodymyr ${ }^{3}$
}

DOI: dx.doi.org/10.30525/978-9934-571-30-5_7

\begin{abstract}
The modern Ukraine survives extremely hard times determined by complex processes of economic reintegration, social and political cataclysms. A development of hybrid war, active antiterrorist measures and resultant human losses have led to the restate or renewal of phenomena and ideas (war, wound infection, wound disease, injury, gunshot, tangential, fragmentation effect), which were forgotten long ago after the Second World War. The authors of article present updated on the problem of modern medicinal (liniment) preparations using in complex therapy of wound infection, types of this drugs, prescription quotient on doctor's of a medicine, criteria of effectiveness and prognostic factors. This publication contains information on modern diagnostic and treatment concepts of wound infection, specific genesis of the patients who had a gunshot wounds and combat traumas, general aspects of classification and typology this phenomena. Authors focuses attention on generalized nature of process development, on gross damage of the main structural and functional units of wound locus morbi. The investigation material is presented in the retrospective aspect, based on both personal observations and archival data, and engages different types of regenerative
\end{abstract}

\footnotetext{
${ }^{1} \mathrm{PhD}$, Research Scientists at Laboratory of Antimicrobial Agent's,

State Institution «I. Mechnikov Institute of Microbiology and Immunology National Academy of Medical Sciences of Ukraine", Ukraine

${ }^{2} \mathrm{PhD}$, Leader Research Scientists at Laboratory of Viral Infection,

State Institution «I. Mechnikov Institute of Microbiology and Immunology National Academy of Medical Sciences of Ukraine", Ukraine

${ }^{3}$ Postgraduate Student at Laboratory of Antimicrobial Agent's,

State Institution «I. Mechnikov Institute of Microbiology and Immunology National Academy of Medical Sciences of Ukraine", Ukraine
} 
reparation of wound, consequence, quotient to surgical treatment (tissue dissection, local transplantation). Authors of present article based of own conclusions in concepts about defined trauma as physical injury and considered the mechanisms and tissue effects by various physical agents produce injury. Wound production is most often the results of the transfer of kinetic energy energy of motion - from one object to another. Four factors contribute to wound production to mechanical trauma (the amount of energy involved, the duration of the impact that causes energy transfer to body tissues, the surface area over which the transfer occurs, the physical characteristics of the tissue that receives the energy). The purpose of the planned study principles of medicinal (lenimental) preparations using on treatment of the general wound forms, detected level of influence microorganisms on its clinical course, stages and characteristic. The research methodology was based on a algorithm of a complex of clinical, microbiological, morphological retrospective methods. Clinical manifestation of wound are inflammatory (open forms). The scientific novelty of the obtained results consists in the use of the ointment drug for the increasing effectiveness of the complicate wound forms treatment. As a result of the study an antimicrobial activity of this drug (application) was proved.

\section{1. Вступ}

3 огляду на ситуацію, що склалась на сході України, відносно невисокий рівень іiі прогнозування, детального визначення причин втрат живої сили особистого складу підрозділів, стає зрозумілою актуальність дослідження провідних аспектів ранової патології та ефективного застосування лікарських (мазевих) препаратів з метою їхнього усунення [1, с. 288-290]. Рани і ранова патологія (у тому числі, поранення) являють собою дещо різні поняття. Якщо рана є локальним проявом /компонентом поранення, то, власне, поранення акумулює в собі уяву щодо акту нанесення рани, iї морфологічного субстрату ушкодження та викликаних зазначеними явищами порушень стану цілісного макроорганізму. Раною вважають механічне ушкодження тканин (можливо пов'язане чи посилене впливом хімічних, біологічних чинників), що супроводжується порушенням цілісності шкіри /слизової та характеризується наявністю трьох кардинальних симптомів - болем, крововиливами та зяянням. Морфологія ран доволі широко спектральна, у зв'язку із чим класифікаційні домінанти 
грунтуються на багато чисельних ознаках [4, р. 599-602]. Найбільш поширеними у сучасній медицині традиційно залишаються обставини виникнення/ нанесення ран (хірургічні/операційні, бойові, випадкові), механізми ушкодження та особливості зброї, із застосуванням якої вони були нанесені (різані, колоті, рубані, вогнестрільні, укушені, потрощені/розміжчині, змішані). У залежності від форм вирізняють рани дірчасті, зірчасті, лінійні, клаптикові, зі втратою речовини чи без неї. У разі втрати великих ділянок шкіри, а також за умов формування значних за розмірами відшарованих іiї шматків рани називають скальпованими [4, p. 599-610]. Коли за умов виникнення рани трапляється втрата частини кінцівки - пальців чи кисті, - мова йдеться про травматичну ампутацію [2, p. 891-899]. У відповідності до фізіологічного стану ранової порожнини рани розрізняють на ті, що мають малу та велику зони ушкодження тканин Стінки ран першої групи морфологічно чітко диференційовані, зберігають життєздатність, тотальному некрозу піддаються лише ті ділянки, з якими зброя контактує безпосередньо. До другої групи відносять рани, у стінках яких тканини нежиттєздатні (розірвані, розм'яті, імбібовані кров'ю, зазнали позначеного топографічно первинного травматичного некрозу) [7, p. 159-164]. Звертає увагу на себе той факт, що форма ран у таких випадках видається більш складною, ніж за умов малих за розмірами вогнищ ушкодження. Класичними представниками першої групи ран $є$ колоті та різані рани. Рубані та вогнестрільні рани посідають проміжну позицію (іноді можуть мати як незначну так і позначену площу ушкодження оточуючих виразку тканин). Всі інші, згадані вище типи ран традиційно вважають представниками другої групи. 3 хірургічної точки зору, надто важливим залишається коректний розподіл вогнестрільних ран на черкані, крізні, сліпі, коли на дні ранового каналу можливе знаходження кулі чи уламків пристроїв. 3 точки зору морфологічного субстрату поранення, розрізняють рани м'яких тканин (шкіра, м'язи), рани із ушкодженням кісток (відкриті переломи), нервів, кровоносних судин та суглобів. У залежності до порожнин людського тіла рани розподіляють на з проникненням чи без нього, з ураженням чи без ураження внутрішніх органів. 3 огляду на наявність та вплив мікрофлори виділяють рани асептичні, бактеріально заражені та інфіковані. Зрозумілим $\epsilon$ той факт, що асептичними можна вважати рани хірургічні, нанесені у разі проведення, так званих, чистих операцій. 


\section{2. Провідні постулати генезу загоювання ран}

Рановий процес, під яким розуміють розвиток низки послідовних біологічних явищ у ранових тканинах, за комфортних умов фінішує остаточним загоєнням. Основні фази загоєння ран класично у патологічній фізіології грунтуються на концептах, висунутих І.В. Давидовським, та долучають перше очищення або підготовчу, запалення або попередньої регенерації, остаточної регенерації [4, р. 599-610]. У разі поранення будь - якого характеру виникає рефлекторний спазм судин, після чого його паралітична дилатація із гальмуванням кровообігу, підвищенням проникливості судинної стінки та розвитком набряку зі всіма наступними реакціями генезу відновлення ран. Одним із таких логічно розпочатих явищ стає природне вичавлення із рани кров'яного згустку за рахунок збільшеного набряком об'єму оточуючих locus morbi тканин. Власне, цим чином здійснюється «первинне очищення рани».3 іншого боку, розвиток ранового/травматичного набряку супроводжується суттєвими розладами тканинного обміну з подальшим порушенням електролітного балансу, ознаками локального ацидозу, осмотичної гіпертонії. Як результат, стає поява продуктів обміну, що стимулюють зростання потенціалу проникливості клітинних мембран, вкрай токсичних для клітин. Загибель та подальше руйнування структурних компонентів клітин тканинної зону ранового ушкодження ініціюється під впливом токсичних речовин, що виділяються у разі розпаду тканин, які зазнали первинного травматичного некрозу. Додаткового негативного зиску у загальну картину надають процеси плазмолізу, викликаного, у тому числі, гідратацією колоїдів та підвищенням осмотичного тиску. Всі ці біохімічні та біофізичні зміни у тканинах, задіяних рановим процесом ділянок, загалом мають ідентичні класичному запаленню ознаки [8, p. 3-89]. I все ж травматичний набряк на сьогодні вважають лише спрощеним варіантом класичної запальної реакції. На користь останнього можуть свідчити такі аргументи, як різке зниження кровопостачання на тлі виразної ішемії тканин. До цього вагомим фактом залишаються збої у компонентному складі запалення. Мова йдеться про так званий неповний «набір» резервів реакцій запалення (ексудативна складова, проліферативна). У разі ран та ранової патології наявно представлені альтеративні процеси (загибель клітин), тоді як ексудація фагоцитарного компоненту незначна, а проліферація у переважній більшості випадків відсутня взагалі. Гальмування дру- 
гої фази ранового процесу (запальної) набряк призводить до поширеного вторинного некрозу, що ще не встигли загинути у наслідок самої травми. Різким і тривалим виявляється набряк у разі масштабних ран 3 великою зоною ушкодження, особливо нанесених вогнепальною зброєю. Контакт із численними факторами рано утворюючого процесу спонукає інтенсифікацію розвитку некротичних процесів у фазі вторинного некрозу. За сприятливих умов перебігу ранового процесу розпаду та порушеного обміну речовин, всмоктуються із уражених тканин та починають відігравати роль нейрогуморальних стимуляторів запальних процесів. Коли останні реалізуються у повному обсязі, починається друга фаза ранового процесу (запалення або попередньої регенераціï) [4, р. 600-609]. Окремі фахівці вважають, що провідну роль у процесах загоєння ран відіграють не специфічні властивості подразників, а їхня інтенсивність (потужні подразники пригнічують репаративно-регенеративні процеси, слабкі призводять до стимуляціiі). Розвиток другої фази ранового процесу стимулює явища, характерні для запальних процесів у цілому, з подальшими демаркацією, відторгненням тканин, що зазнали первинного чи вторинного некрозу. У решті решт, відбувається остаточне очищення ран, яке класично іменують біологічним. У третій фазі ранового процесу активізуються реакції, пов'язані із заповненням дефекту грануляційної тканиною та епітелізацією поверхні останньої. Чіткої межі між другою і третьою фазами встановити не можливо, у зв'язку із тим, що репарація починається до завершення демаркаційного запалення і відбувається у паралелі із процесами очищення ран. У певних випадках явища та процеси, властиві другій та третій фазам, майже цілком співпадають у часі. Можливість розмежування фаз ранового процесу зумовлюється виключно тим, яким саме шляхом відбувається загоєння (первинного чи вторинного натягнення). За для реалізації першого варіанту обов'язковим чином повинні співпадати три умови. По-перше, зяяння рани відсутнє/штучно усунене, ранова порожнина має вигляд вузької щілини. По-друге, для рани характерна незначна зона ушкодження оточуючих тканин. Рана асептична/хірургічна (останніми дослідженнями доведено, що згадана умова не є обов'язковою у тому сенсі, що наявність мікрофлори у рані не завжди заважає розвитку первинного натягнення у ній) [10, p. 317-322]. За умов першого варіанту загоєння ран запальні реакції розвинуті слабко. Невеликі ділянки некротизованої 
тканини розсмоктуються, не висуваються у зовнішній простір, згустки крові та серозно-фіброзного ексудату, що можуть заповнювати рану та склеювати їі краї, теж піддаються розсмоктуванню, організуються, проростають молодою сполучною тканиною. Протягом першого тижня фіброзні нашарування рани замінюються грануляціями. Епітелізація за умов первинного варіанту може відбуватися як поверхнево, так i під струпом первинного нашарування. У разі повного співпадання всіх трьох фаз ранового процесу, його фінал знаменує формування тонкого лінійного рубця. Вторинний варіант загоєння (нагноєнням та через грануляції) відбувається у тих випадках, коли стінки ран нежиттєздатні чи на відстані зосереджені одна від одної, мають велику зону ураження, за умов інфікування ран, зяючих ран з великою втратою речовини [9, р. 32-37]. Велика відстань між краями та стінками такої рани не сприятливі для формування фіброзного шару, який маючи незначну площу розташування у зонах дефектів ніяким чином не локалізує останні та не захищає від впливу зовнішнього середовища. Вторинний варіант загоєння ран відбувається за лаштунками демаркацій та розплавлення фіброзних мас (очищення рани), відторгнення некротичних мас. Процес завжди супроводжується виділенням гнійного ексудату та залежить від поширеності некротичних змін, характеру субстратів для відторгнення. 3 одного боку, процеси біологічного очищення тривають тиждень чи менше, за інших умов, - воно може мати пролонгований характер. Третя фаза процесу нашаровується на попередню, процеси репарації розвиваються лише після остаточного біологічного очищення ранової поверхні. Останні, як і у випадку з першим варіантом, грунтуються на явищах заповнення рани тотальними масами грануляцій за позначеними масштабами дефекту. Процеси епітелізації у таких випадках починаються 3 країв шкіри. Периферичні ділянки грануляцій перетворюються у рубець (масивний, неправильної форми, доволі поширений топографічно), який утруднює функціонування кінцівки та може призвести у задавнених випадках до отримання інвалідності. Тривалість третьої фази ранового процесу різна. У разі великих дефектів, погіршеному стані поранених, приєднанні мікрофлори, загоєння ран може затримуватись.

Безпрецедентним $є$ той факт, що зяяння рани обов'язковим чином призводить до втручання до неї мікробів. Навіть у разі хірургічно нанесеної рани неможливо ії вберегти від вторинного забруднення особливо 
у тих випадках, коли остання має відкритий характер [6, p. 424-430]. Випадкові та бойові рани забрудненими виявляються первинно, за чим, як правило, додається вторинне забруднення [1, с. 290-292]. Характер та ступень впливу мікрофлори на рану визначають відмінність рани бактеріально забрудненої (у якій наявність та розвиток мікробів не обтяжують перебігу ранового процесу) та інфікованої (де вплив мікрофлори значно обтяжує перебіг ранового процесу).

\section{3. Місцеві лікарські засоби}

у сучасному комплексному лікуванні ран та ранової патології

У сучасній комплексній терапії ран та ранової патології широкого застосування знайшли мазі, креми і гелі. Метою використання зазначених лікарських форм є досягнення найбільш високого рівня активації регенераторних реакцій, прискорення процесів загоєння ран, створення асептичних умов у зоні ранового процесу, усунення ознак запальних процесів та попередження розвитку некрозу [4, p. 600-610]. Зазначені засоби у залежності від хімічного складу здатні до поліпшення місцевого кровообігу, (що вкрай важливо, з патофізіологічної точки зору, у посиленні відновного потенціалу ушкоджених тканин), усунення дефектів периферичної інервації. Існують грунтовні спостереження на користь властивостей зазначених препаратів до збереження естетичної складової ураженої ділянки/зони м'яких тканин. У повсякденній медичній практиці терапії ранової інфекції застосовується широкий спектр мазей на жировій і вазелін-ланолінової основі: мазь Вишневського, синтоміцинова емульсія, мазі з антибіотиками (тетрациклінова, неоміцинова та ін.) [3, p. 116-124]. 3 огляду на якість та поміркований зиск застосування цих препаратів, слід пам'ятати щодо окремих негативних моментів їхнього застосування. Серед останніх на одному із перших місць залишається гідрофобність, завдяки якій мазь хоча і захищає ранову поверхню ушкодженого субстрату, проте, й відіграє роль своєрідної корки, котра не вбирає вологу та не забезпечує відтоку ранового секрету. 3 іншого боку, антибіотики, що містяться у складі зазначених мазей, не звільняються з їхніх композитів і не надають достатньої антимікробної дії [9, р. 32-37]. У зв’язку із цим, патогенетично обгрунтованим стало застосування нових гідрофільних водорозчинних мазей - Левосин, Левомиколь, Мафенід-ацетат. Осмотична активність цих мазей перевищувала дію гіпертонічного розчину 
в 10-15 разів, і утримувалась на певному рівні протягом 20-24 годин (таким чином, для ефективної дії на рану достатньою видавалась одна перев'язка на добу). 3 огляду на те, що головним завданням другої фази регенерації ранового процесу $є$ епітелізація та рубцювання ран, як додатковий ефективний засіб застосовували речовини рослинного походження - сік алое, обліпихи, каланхое, шипшинову олію. Препарати, що давно і успішно застосовуються у згаданій галузі медицини, можна об'єднати у такі групи.

Препарати алое. Алое - одна з найперших рослин, яку людство почало застосовувати з лікувальною метою. Через наявність у складі соку алое величезного числа біологічно-активних речовин, вітамінів, мікроелементів та інших корисних компонентів, їй притаманний великий діапазон факторів позитивного впливу на організм у цілому та окремі системи органів, зокрема. У практиці лікування ран та ранових поверхонь широко застосовується протизапальна, бактерицидна, потужна регенеруюча дія алое. 3 успіхом застосовується для вирішення безлічі шкірних проблем ефективні препарати, що створені на основі компонентів алое. Добре відомі відмінні результати зі зняття запалень, загоєння опіків, інфікованих ран [9, р. 32-37]. Препаратами алое ефективним є позбавлення від вугрової хвороби, прищів, виразок, наривів тощо. При захворюваннях шкіри, таких, як хронічна ранова хвороба (що може розвиватися на тлі цукрового діабету під впливом певних механічних факторів втручання), трофічні виразки, свищі, нариви для отримання позитивного результату рекомендовано застосовувати суміші $(1: 1)$ соку алое з додаванням інших лікарських компонентів (сік чистотілу, спиртовий настій прополісу, мед, якщо мова йдеться не про діабетичний анамнез) зі столовою ложкою винного (етилового) спирту. Зазначений препарат наноситься на уражені ділянки двічі на добу, утримується під стерильною пов'язкою. Умови збереження доволі доступні і підтримуються зоною охолодження побутового холодильника.

Препарати, що застосовуються на основі масла обліпихи. Особливість згаданих речовин грунтується на ідеальній збалансованості всіх вітамінів та мікроелементів, що входять до іiі складу. Корисні лікувальні властивості обліпихової олії обумовлені синергізмом (взаємно посилюючою дією всіх іiі компонентів). За вмістом каротиноїдів обліпихова олія вигідно вирізняється від інших рослинних масел, а за 
вмістом вітаміну С поступається лише шипшиновій. Опіки, неглибокі поверхневі ранки, пролежні, обморожені ділянки шкіри за чисельними та багаторічними спостереженнями фахівців цілком можна вилікувати завдяки тривалому використанню настою з обліпихи. Пришвидшенню репараційних реакцій великою мірою сприяють попереднє застосування фурациліну з подальшим щоденним накладанням пов'язки, насиченої маслом обліпихи.

Поширеного застосування у лікуванні ран, у тому числі інфікованих, знайшов дьоготь березовий, відомий продукт переробки зовнішньої частини кори берези. Густа масляниста рідина 3 доволі високим вмістом фенолу, толуолу, ксилолу та інших рослинних смол активно застосовується зовнішньо при шкірних захворюваннях (як 10-30\% мазевий препарат та лінімент). Антисептичний лікувальний ефект зазначеного $\epsilon$ результатом не лише місцевої терапевтичної дії (поліпшення кровопостачання тканин, посилення процесів регенерації) шкіри, але й як відповідь на подразнення іiі рецепторів. Ефективність речовини забезпечила їй статичну складову участь у мазях Вількінсона, Вишневського. За умов тривалого застосування дьогтю іноді можливі подразнення шкіри та загострення екзематозних процесів.

Відомим «гравцем» на фармацевтичному ринку із числа препаратів, що традиційно застосовуються у лікуванні ранових процесів залишається бальзам Вишневського. Цей препарат має більш, ніж вікову історію та є одним із найбільш ефективним, доступним, нешкідливим. Результативність бальзаму забезпечується його складом: три частини дьогтю, стільки ж частин ксероформу та 94 частини касторового масла. Спектр застосування поширюється від лікування ран, пролежнів до трофічних виразок, тощо. Для бальзаму характерні антисептичні властивості, маловиразна подразнююча дія, стимулюючий вплив на регенеративний потенціал. Мазь Вількінсона відрізняється від бальзаму за вибором компонентів (дьоготь рідкий - 15 частин, кальцій карбонат (крейда) - 10 частин, сірка очищена - 15 частин, мазь нафталанова 30 частин, зелене мило у кількості до 30 частин та 4 частини води дистильованої). Згаданий препарат використовують у якості антисептика для зовнішнього застосування як антисептичний засіб (короста, грибкові захворювання шкіри, тощо).

Доволі перспективні результати отримані у разі застосування антибактеріального препарату іманіну, що синтезований із звіробою 
звичайного. Специфічною рисою цього лікарського засобу є здатністю підсушувати ранову поверхню і стимулювати регенерацію тканин. Застосовується цей медикамент як антисептик у вигляді розчинів, мазей, присипок для лікування свіжих та інфікованих ран, опіків, виразок, абсцесів, тріщин сосків, маститів, фурункулів, карбункулів. Спектр застосування іманіну поширюється на внутрішню медицину (лор-хвороби, офтальмологія). Відомі позитивні результати використання іманіну у разі розвитку гострих ларингітів, гайморитів, ринітів. Розчином цього препарату прийнято зрошувати, обмивати уражені місця, накладати у вигляді щодобових вологих пов'язок. Концентрація діючої речовини не повинна перевищувати 5-10\%. Найбільш застосовуваним $є$ мазеві препарати з іманіном.

Добре відомі на теренах сучасної фармакопеї препарати настоянок календули та софори японської. Спиртові настоянки квітів і квіткових кошиків нагідок являються ефективними антисептиками у разі виникнення випадкових порізів, виникнення гнійних ран, опіків. Ці препарати мають показові результати при лакунарних ангінах, тонзилітах, фарингітах. Традиційно застосовують календулу для полоскань горла, промивання ротової порожнини у разі стоматитів, гінгівітів. Відомі позитивні результати від прийому процедур з розчином насідків після екстирпаційного хірургічного втручання (складні видалення зубів у пацієнтів із алергічними реакціями). За цим рекомендовано застосовувати розчини з розрахунку - 1-на чайна ложка настою на склянку води. У внутрішній медицині настоянку календули вживають як ефективний жовчогінний засіб (10-20 крапель на прийом). Ефективність настоянки софори японської полягає у іiі виразних антисептичних властивостях, що добре позначаються на результатах лікування гнійних запальних процесів (рани, опіки, трофічні виразки). Препарат рекомендований для зрошення, промивання, накладень вологих пов'язок.

Із давніх давен відоме своїми протизапальними та антимікробними властивостями листя подорожника. Навіть сам лист без застосування сумішей препаратів сприяє загоєнню ран, надає протизапальну дію, має антимікробний вплив. Найпростіший спосіб приготування найбільш доступної лікарської сировини - пропустити рослину через м'ясорубку, змішати з ланолином та вазелином у співвідношенні $1: 1: 8$ або змішати подорожник із персиковим маслом у співвідношенні $1: 9$ [8, p. 2-6; p. 81-94]. 
На сьогодні також успішно застосовується натрієва сіль усніновой кислоти, виділеної з лишайників. Вона є визнаною антибактеріальною речовиною. Призначають як антисептик у вигляді 1\% водно-спиртового або $0,5 \%$ масляного розчину (на касторовій олії), а також у вигляді розчину в гліцерині, ялицевому бальзамі. Розчинами рясно змащують марлеві пов'язки, які накладають на уражену поверхню шкіри. При припудрюванні ран порошком витрачають 0,1-0,2 г на рану розміром близько 15-20 кв см. Мазь для загоєння ран може мати як антимікробну, так і антибактеріальну властивість. Багато препаратів використовуються і як антисептичні, протизапальні, регенеруючи засоби.

Купуючи мазі для загоєння ран, важливо знати та враховувати їхню класифікацію. Засоби вибирають у залежності від етіології (причини) і фази ранового процесу. Якщо рана глибока, потрібно застосовувати антибактеріальний препарат, з ефектом знеболення. Якщо зона ушкодження має ознаки розвитку запальних реакцій, необхідно використовувати антисептик, протимікробний мазевий препарат. Завершальна стадія ранового процесу вимагає засоби, що стимулюють регенераційні процеси у шкірі. Зазначені препарати за складом розподіляються на: протимікробні (з антибіотиками), препарати ферментів (на основі амінокислот, протеаз, хімотрипсину та інших). Застосовуються такі речовини у комплексі з іншими гелями і мазями. Як допоміжні засоби терапії можливі ліки, що містять рослинні екстракти (сік алое, каланхое, масло обліпихи, календули, прополіс). Такі препарати забезпечують термінове усунення явищ запалення, ексудації, інтенсивно відновлюють шкіру.

3 огляду на останнє, потрібно пам'ятати хоча б нечисленний перелік найбільш ефективних та затребуваних препаратів, що знайшли своє застосування у лікуванні ран, ранової патології. Одним із перших окремими фахівцями названо крем «Аргосульфан®». Останній відомий позначеними результатами у загоєнні невеликих ран, виразок. Поєднання антибактеріального компоненту сульфатіазолу срібла та іонів срібла забезпечує широкий спектр антибактеріальної дії згаданому крему. Наносити препарат можна не лише на рани, розташовані на відкритих ділянках тіла, а й під пов'язки. Засіб має не лише ранозагоювальну, але і протимікробну дію, сприяє регенерації ран поза формування колоїдного рубця. Іншим препаратом зазначеного спектру $є$ мазь «Банеоцин». В її складі нараховують два антибіотики - неоміцин 
і бацітран. Ефективність засобу доведена у разі лікування глибоких ран, опіків, обробки швів після операцій на черевній, грудній порожнинах. Швидким рятівником від наслідків, що виникли у разі розвитку вогнищ інфекцій, є доволі поширений, добре відомий та визнаний на теренах колишнього СНД фармацевтичний засіб «Левомеколь». Спектр застосування «Левомеколю» достатньо широкий, показання до застосування майже не обмежені, терміновість дії до зони інфекційного ураження виразна [5, p. 1195-1205]. Оперативна галузь хірургії вважає цей засіб універсальним з огляду на рівень його бактерицидних властивостей (обробка швів, locus morbid, тощо). До останнього препарату слід також віднести класично відому цинкову мазь (недорогий, собі вартісний засіб, здатний загоювати відкриті рани, підсушувати мокрі поверхні зони уражень, післяопераційні шви). Перспективним 3 огляду на свій вітамінний склад залишається препарат «Аекол». (Містить ретинол, менадион, бета-каротин і вітамін Е). 3 точки зору поліпшення місцевої трофіки, прискорення регенерації $є$ «Метилурацил». Своє найбільш поширене застосування засіб знайшов у гінекологічній галузі. Як препарат, виготовлений на основі алое, він добре демонструє протизапальну, антибактеріальну, стимулюючу дію.

Широкого застосування у повсякденній практиці лікування ранової інфекції зазнав препарат «Актовегін». Він активно сприяє загоєнню неінфікованих ран, опіків, пролежнів, стимулює клітинний метаболізм 3 подальшим зростанням регенеруючого потенціалу зони ушкодження [10, p. 14-31]. Ефективність засобу певним чином визначає діюча речовина - депротеінізований гемодериват (витяжка з крові телят, звільнена від білкової маси методом ультрафільтрації). Застосування останнього полягає у накладенні щоденних пов'язок, рясно просочених маззю. Близьким аналогом «Актовегіну» є «Солкосерил». Засіб вироблений на основі екстракту телячої крові. Знімає біль, відновлює тканини. Деякі відмінності в характері впливу засобу зумовлені різними технологіями виробництва, застосовуваними фармацевтичними фірмами. Солкосерил випускається у тих же лікарських формах (желе, мазь, гель), що і «Актовегін», спектр показань до застосування ідентичний [9, р. 32-37]. У пролонгованому лікуванні ран, опіків, тріщин сосків широкого застосування зазнали препарати «Бепантен» та «Бепантен плюс». Цікавим фактом $є$ здатність засобів за рахунок вітаміну В5 стимулювати синтез колагену, прискорювати клітинний обмін. Охоче 
застосовуються препарати у педіатрії з метою ефективного усунення попрілостей, пелюшкового дерматиту у немовлят. Для зазначених ліків також характерними є пом якшувальна, знеболююча та виразна заспокійлива дія. Бепантен плюс за аналогічним до біпантену складом (лише додано речовину антибактеріального напрямку дії- хлоргексидин гідро хлорид), ефективно захищає рану від інфікування. Як препарат привентації його застосовують у мамології з метою попередження розвитку запальний процесів у сосках молочних залоз жінок, що вигодовують немовлят. Із числа препаратів зовнішнього застосування відомий «Пантенол» (з активною речовиною дексапентенолом). Призначається у комплексній терапії для прискорення процесу епітелізації ранових поверхонь шкіри (післяопераційні пошкодження, опіки, травматичні рани). Його спрейовий аналог - ефективний репарант. Як і мазі на основі пантотенової кислоти, застосовується у лікуванні ран, опіків різного походження; прискорює синтез колагену, має охолоджуючу пом`якшувальну дію. Балон, наповнений піною під тиском, акуратно наноситься на відкриті, сухі або вологі рани. Позитивними факторами застосування є відкритість locus morbi, що прискорює загоєння під тиском постійного припливу повітря. Накладання пов`язки не $є$ обов'язковим принципом у лікуванні ранової патології із застосуванням «Пантенолу» та обумовлюється лише захистом від контакту із факторами зовнішнього середовища (одяг, пил, тощо).

Що стосується терапії суто шкірних хвороб, доволі успішним препаратом вибору за цим вважають «Радевіт» (діюча речовина ретинолу пальмітат, вітамін «А»). Вказану мазь застосовують у лікуванні себорейних дерматитів, іхтіозу, ерозій, опіків, деяких видів нейродермітів, тріщин, що утворюються у разі виникнення авітамінозів. Регенеруюча дія цього препарату обумовлена здатністю вітаміну «А» прискорювати обмінні процеси, блокувати дію вільних радикалів. Для усунення факторів виникнення акне, вугрових висипів у відомих на сьогодні схемах лікування застосовують мазь (гель) «Куріозін» (гіалуронат цинку). Препарат має антисептичну дію, активізує кровообіг і мікроциркуляцію, покращує живлення дерми, активізує синтез колагену. У косметології засіб використовують в програмах омолодження (розгладження зморшок, оздоровлення шкіри) [8, р. 24-39].

Серед препаратів, що є продуктами бджільництва, найбільш широкого застосування отримав оригінальний лікарський препарат «Про- 
лефен» (Prolefenum). Випускається засіб у формі мазі (30,0 г). Використовується медикамент для лікування ран, опіків, виразок, що довго не загоюються. Характеризується ранозагоювальними, протизапальними та антимікробними властивостями. «Пролефен» сприяє проліферації опікових уражень, підсилює процеси епітелізації та репарації ран. Рекомендується у схемах лікування ран, поверхневих і глибоких опіків (стадії проліферації опікового ураження). С сенс застосовувати засіб як додатковий препарат для лікування трофічних виразок, глибоких ранових ушкоджень. Іншим оригінальним лікарським засобом, що виготовлений на сонові продуктів бджільництва $є$ «Пропаскан» (Propascanum) паста. Рекомендований у схемах лікування ран, опіків, виразок. Для препарата є характерною захисна дія по відношенню до органічних розчинників. «Пропаскан» проявляє антимікробну, протизапальну та ранозагоювальну активність, сприяє проліферації опікових уражень, підсилює процеси епітелізації та репарації ран. Протипоказаннями до застосування є індивідуальна нестерпність до продуктів бджільництва, алергійні реакції.

\section{4. Висновки}

3 огляду на ситуацію, що склалась на сході України, сучасна ранова патологія не втрачає своєї актуальності ні як об'єкт експериментальних, так і клінічних досліджень. Якщо рана є локальним проявом /компонентом поранення, то, власне, поранення акумулює в собі уяву щодо акту нанесення рани, іiі морфологічного субстрату ушкодження та викликаних зазначеними явищами порушень стану цілісного макроорганізму. Основні фази загоєння ран грунтуються на концептах, що орієнтовані на три послідовних фази: перше очищення або підготовчу, запалення або попередньої регенерації, остаточної регенерації. Можливість диференціації фаз ранового процесу визначається саме типом загоєння ран (первинний чи вторинний варіанти натягнення). Умовами першого варіанту є незначна зона ушкодження, відсутність зяяння та асептичність самого дефекту. Загоєння ран за алгоритмом другого варіанту долучають наявність мікрофлори, iї зяяння, нежиттєздатність країв та стінок. Препарати вибору у лікуванні ранової патології неодмінним чином повинні сприяти досягненню найбільш високого рівня активації регенераторних реакцій, прискоренню процесів загоєння ран, створенню асептичних умов у зоні ранового процесу, усуненню 
ознак запальних процесів та попередженню розвитку некрозу. Зазначені засоби у залежності від хімічного складу здатні до поліпшення місцевого кровообігу, (що вкрай важливо, з патофізіологічної точки зору, з метою посилення відновного потенціалу ушкоджених тканин), усунення дефектів периферичної інервації.

\section{Список літератури:}

1. Цимбалюк В.І. Оцінка танатологічного профілю зони бойових дій (погляд судово-медичного експерта) / В.І. Цимбалюк, В.О. Ольховський, I.I. Торяник та ін. // Актуальні проблеми сучасної медицини. - 2017. - Том 17, випуск 3 (59). - С. 288-292.

2. Driver, V.R., Lavery, L.A., Reyzelman, A.M., (2015). A clinical trial of Integra Template for diabetic foot ulcer treatment. Wound Repair Regen, 23 (6), 891-900.

3. Dryden, M.S. (2014). Novel antibiotic treatment for skin and soft tissue infection Curr Opin Infect Dis, 27 (2), 116-124.

4. George, Han, Roger, Ceilley (2017). Chronic Wound Healing: A Review of Current Management and Treatments Adv Ther, 34 (3), 599-610.

5. Hill, K. E., Malic,C., McKee, R., Rennison, T., Harding, K.G., Willians, D.G. \& Thomas, D.G. (2010). An in vitro model of chronic wound biofilms to test wound dressings and assess antimicrobial susceptibilities. Journal of Antimicrobial Chemotherapy. 65(6), 1195-1206.

6. Hori, K., \& Matsumoto, S. (2010). Bacterial adhesion: from mechanism to control. Biochemical Engineering Journal, 48 (3), 424-434.

7. Miller, A.C., Rashid, R.M., Falzon, L., Elamin, E.M., Zehtabchi, S. (2012). Silver sulfadiazine for the treatment of partial-thickness burns and venous stasis ulcers J Am Acad Dermatol, 66(5), 159-165.

8. Paulson D. S. Biostatistics and microbiology: a survival manual/D. S. Paulson// Springer Science \& Business Media. - 2008. - 100 p.

9. Sharmina Aftab, Md. Monowar Tarik, Dr. Mohammad Abdullah Yusuf (2014). Clinical and Microbiological Aspect of Wound Infection: A Review Update. Bangladesh Journal of Infectious Diseases, 1 (2), 32-37.

10. Wolcott, R.D., Gontcharova, V., Sun, Y., Zischakau, A., \& Dowd, S.E. (2009). Bacterial diversity in surgical site infections: not just aerobic cocci any more. Journal of Wound Care, 18 (8), 317-323.

\section{References:}

1. Tsymbaliuk V.I. (2017) Otsinka tanatolohichnoho profiliu zony boiovykh dii (pohliad sudovo-medychnoho eksperta) / V.I. Tsymbaliuk, V.O. Olkhovskyi, I.I. Torianyk ta in. // Aktualni problemy suchasnoi medytsyny, 17, 3 (59), 288-292.

2. Driver, V.R., Lavery, L.A., Reyzelman, A.M., (2015). A clinical trial of Integra Template for diabetic foot ulcer treatment. Wound Repair Regen, 23 (6), 891-900. 
3. Dryden, M.S. (2014). Novel antibiotic treatment for skin and soft tissue infection Curr Opin Infect Dis, 27 (2), 116-124.

4. George, Han, Roger, Ceilley (2017). Chronic Wound Healing: A Review of Current Management and Treatments Adv Ther, 34(3), 599-610.

5. Hill, K. E., Malic,C., McKee, R., Rennison, T., Harding, K.G., Willians, D.G. \& Thomas, D.G. (2010). An in vitro model of chronic wound biofilms to test wound dressings and assess antimicrobial susceptibilities. Journal of Antimicrobial Chemotherapy. 65 (6), 1195-1206.

6. Hori, K., \& Matsumoto, S. (2010). Bacterial adhesion: from mechanism to control. Biochemical Engineering Journal, 48 (3), 424-434.

7. Miller, A.C., Rashid, R.M., Falzon, L., Elamin, E.M., Zehtabchi, S. (2012). Silver sulfadiazine for the treatment of partial-thickness burns and venous stasis ulcers J Am Acad Dermatol, 66 (5), 159-165.

8. Paulson D. S. Biostatistics and microbiology: a survival manual / D. S. Paulson // Springer Science \& Business Media. - 2008. - 100 p.

9. Sharmina Aftab, Md. Monowar Tarik, Dr. Mohammad Abdullah Yusuf (2014). Clinical and Microbiological Aspect of Wound Infection: A Review Update. Bangladesh Journal of Infectious Diseases, 1 (2), 32-37.

10. Wolcott, R.D., Gontcharova, V., Sun, Y., Zischakau, A., \& Dowd, S.E. (2009). Bacterial diversity in surgical site infections: not just aerobic cocci any more. Journal of Wound Care, 18 (8), 317-323. 